\title{
Application of analytical hierarchy process (AHP) in prioritizing HAZOP analysis for pilot plant
}

\author{
Hanida Abdul Aziz, Mohamad Rizza Othman', Azmi Mohd Shariff ${ }^{3}$ and Lian See Tan ${ }^{4}$
}

\begin{abstract}
${ }^{I}$ Occupational, Safety and Health Program, Faculty of Engineering Technology, Universiti Malaysia Pahang, 26300 Gambang, Pahang, Malaysia. ${ }^{2}$ Process Systems Engineering Research Group, Faculty of Chemical Engineering and Natural Resources, Universiti Malaysia Pahang, 26300 Gambang, Pahang, Malaysia. ${ }^{3}$ Centre of Advanced Process Safety, Department of Chemical Engineering, Universiti Teknologi PETRONAS, 31750 Tronoh, Perak. ${ }^{4}$ Department of Chemical \& Petroleum Engineering, UCSI University, 56000 Kuala Lumpur, Malaysia. Article Info: Submitted on March 20, 2017, Accepted on June 20, 2017.
\end{abstract}

\begin{abstract}
Injuries, accidents or even fatalities while working in pilot plant are reported worldwide. The implementation of process hazards analysis (PHA) in pilot plant is expected to further reduce the risks of accidents. Hazard and operability (HAZOP) analysis is one of the most widely used methods for PHA. Generally, the outcome of HAZOP analysis could results in identifying large number of hazards thus poses a challenge for assessors to take actions in dealing with all the hazards. The common practice in prioritizing the critical hazards is based on assessors' experience through deductive judgment using rating scale, taking into consideration safety and the associated costs. However the novel operations and process used, unproven or changing technology, and lack of safety information due to developmental stages have led to poor hazards prioritization and difficulty in selecting actions. This paper presents an application of analytical hierarchy process (AHP) in prioritizing HAZOP analysis for pilot plant. Through this approach, the significant hazards identified using HAZOP will be quantitatively weighted and ranked based on their priority along with the appropriate counter measures to be taken. Application of this approach at the high pressure CO2-hydrocarbon absorption system pilot plants as case study showed that the proposed methodology is capable of identifying and ranking the significant hazards in the process following HAZOP analysis. This is particularly useful as a leading indicator to process designers/engineers/researcher in prioritizing their efforts and resources on more significant hazards, hence prevent accidents of the pilot plant.
\end{abstract}

Keywords: Analytic hierarchy process (AHP); Hazard and operability (HAZOP); Pilot plant; Hazards analysis.

\section{Introduction}

Pilot plant occupies a grey area somewhere in the middle of the spectrum from basic research to real process plant production. Some of the items are physically part of research unit operations, whereas others are part of the manufacturing operation. Generally, the volumes of hazardous chemicals in pilot plant are lower than commercial plant and considered to be safe without requiring extra precautions. However the novel operations and processes used, high operation density of equipment, unproven or changing technology, lack of safety related information due to developmental stages, waste generated by the operation, use of sophisticated instruments gives a significant hazard impact that can cause injuries, fatalities and property damage. ${ }^{1-3}$ As an example, in real process plant, the plant layout and equipment safe siting distance normally follows standards to avoid the damaging effect in the case of the accident. However, pilot plant does not have such a standard to follow and normally the users intend to design a compact pilot plant system. The users normally assume it is safe to operate in a compact design due to small quantity of hazardous chemicals to be handled. Due to high density of operating equipment, the risk of the accident may be significant. The various heating devices installed like furnaces, heaters and electrical equipment in the designated area could increase the risk. In the event of the accident such as fire or explosion, it may involve numbers of equipment that varies from reactors to compressors. These equipment have different hazard potential that installed close with each other will make the accident worst.

Hazard recognition in laboratories and pilot plant is generally managed under, either Occupational Safety and Health Administration (OSHA) Laboratory standard 29 CFR 1910.1450 or Hazard Communication standard 29 CFR 1910.1200. Both of these standards emphasize communication of hazard information via a Material Safety Data Sheet (MSDS) and a product label. Many institutions may have their internal guidelines for controlling hazards or risks in chemical laboratories such as Chemical Hygiene Plan. ${ }^{4}$ However, such standards and internal guidelines may have limitation to manage process hazards in the pilot plant. According to Mason ${ }^{5}$ pilot plant is to the development of a potential new production process 


\section{Chemical Engineering Research Bulletin 19(2017) 87-95}

which is specifically exempted from the OSHA Laboratory standard because it fails to meet the definition of 'laboratory'. In addition, West ${ }^{6}$ in his studies classified that pilot plant and full-scale production has similarity in terms of typical stages in assessment of chemicals.

Process hazard analysis (PHA) is imperative for inherent safer design and operation of chemical processes. The implementation of PHA in pilot plant is expected to further reduce the risks associated with the operations in this location. ${ }^{7,8}$ Many methods and tools are available for performing PHA either quantitatively and/or qualitatively. Some of the well-known methods are hazard and operability study (HAZOP), fault tree analysis (FTA), failure mode effect analysis (FMEA) and What-if analysis.All ofthe above methods require their rigorous, thorough, and systematic application by a multidisciplinary team of experts. Success rests upon first identifying and subsequently analyzing possible scenarios that can cause accidents with different degrees of severity. Without a structured identification system, hazards can be overlooked, so entailing incomplete risk-evaluations and potential loss. ${ }^{9}$

Among these, HAZOP is the most widely used and considered as formal procedure to identify hazards in chemical plant. The nature of conducting HAZOP however, is very time-consuming, demanding and exhaustive. ${ }^{10}$ Due to its 'let the mind go free' approach, HAZOP analysis could result in a vast number of hazards being identified. In addition, the HAZOP analysis output however provides limited data only (plus qualitative), thus many of those hazards identified may have low probability or consequences. ${ }^{11}$ The common practice in prioritizing the critical hazards is based on assessors' experience through deductive judgment using rating scale, taking into consideration safety and the associated costs. However, due to the novel operations and process which being used, unproven or changing technology, and lack of safety related information at developmental stages has form a complex decision-making process with interrelated components. ${ }^{2,3}$ This consequently led to poor hazards prioritization and difficulty in selecting actions that address the most substantial hazards especially when safety and cost criteria are involved. Presumably, while interacting with such complex scenarios, the better the decision makers understand this complexity, the better the decision will be.

As an alternative to the addressed issues, analytic hierarchy process (AHP) which is a widely used decision making tool, can be incorporated into the typical HAZOP procedure to provide a mean for prioritization of the risks and consequences. This is to ensure that the most significant hazard(s) is being addressed first properly within the available resources.
AHP is a multi-criteria decision making (MCDM) methodology based on hierarchical structure and it is the most suitable approach for MCDM problems. ${ }^{12}$ Its hierarchical and systematic method makes it a popular technique to solve MCDM problems and have been implemented in few safety related area including selection of contractors for safer turnaround maintenance ${ }^{13}$, selection of safety devices ${ }^{14}$, multiexperts opinion of natural gas pipelines failure. ${ }^{15}$ This paper presents the application of AHP in prioritizing HAZOP analysis outcomes in pilot plant. Application of this approach at the high pressure $\mathrm{CO} 2$-hydrocarbon absorption system pilot plants as case study is examined and discussed.

\section{Materials and Methods}

\section{HAZOP-AHP}

HAZOP-AHP is developed as a methodology that incorporates a multi-criteria decision making approach to prioritize the hazards that may contribute to the undesirable events identified from the HAZOP analysis. The general steps to the methodology are performing HAZOP analysis, constructing problem decomposition hierarchy, performing pairwise comparison matrix, calculating weights ranking and undergo consistency test, developing overall priority ranking and analyzing the HAZOP-AHP results. ${ }^{16}$

In this study, the HAZOP methodology is adopted from Crowl and Louvar. ${ }^{11}$ The analysis was performed by the HAZOP members that comprises of lecturers, research scientist, technologies and post graduate students who directly involves with the operation and experienced with HAZOP study. After the HAZOP analysis table was constructed, Super Decision software (SDS) was used for weight calculation. SDS is one of the AHP tool due to powerful and flexible in making multi-criteria decision. ${ }^{17}$ SDS consists of four steps: (1) building a hierarchy of the objective or goal, (2) entering the alternatives, (3) comparing the elements and finally, (4) synthesizing the result.

Under step 1 and 2, the overall goal, criteria, subcriteria, and alternatives form a linear hierarchy involving all of them in several levels. Each level is tagged with a unique identification numbering system that facilitates the activity tracking. In step 3, pairwise comparison was performed at every level whereby two components are compared with respect to the upper level control criteria using scale of relative importance. The scaling factor is based on established fundamental scale of absolute numbers by Satty $^{18}$ as show in Table1. It is important to note that assigning scale to the elements is subjective thus the assessor's knowledge, experience and judgment is crucial. In this case, setting the scaling factor during the construction 


\section{Chemical Engineering Research Bulletin 19(2017) 87-95}

of pairwise comparison matrix table has been done by the HAZOP team members. The final step in this methodology is analysis of the outcome from the HAZOP-AHP assessment. Since the analysis includes quantitative valuation, the selection of outcomes can be easily rank and prioritized.

Table 1: The fundamental scale of absolute number by (Saaty 1980) ${ }^{18}$.

\begin{tabular}{|c|c|c|}
\hline Intensity & Importance & $\begin{array}{l}\text { Definition } \\
\text { explanation }\end{array}$ \\
\hline 1 & Equal importance & $\begin{array}{l}\text { Two activities } \\
\text { contribute equally to } \\
\text { the objective }\end{array}$ \\
\hline 2 & Weak or slight & \\
\hline 3 & $\begin{array}{l}\text { Moderate } \\
\text { importance }\end{array}$ & $\begin{array}{l}\text { Experience and } \\
\text { judgment slightly favor } \\
\text { one activity over } \\
\text { another }\end{array}$ \\
\hline 4 & Moderate plus & \\
\hline 6 & Strong plus & \\
\hline 7 & $\begin{array}{l}\text { Very strong or } \\
\text { demonstrated } \\
\text { importance }\end{array}$ & $\begin{array}{l}\text { An activity is favored } \\
\text { very strongly over } \\
\text { another, its dominance } \\
\text { demonstrated in } \\
\text { practice }\end{array}$ \\
\hline 8 & Very, very strong & \\
\hline 9 & $\begin{array}{l}\text { Extreme } \\
\text { importance }\end{array}$ & $\begin{array}{l}\text { The evidence favoring } \\
\text { one activity over } \\
\text { another is of the } \\
\text { highest possible order } \\
\text { of affirmation }\end{array}$ \\
\hline $\begin{array}{l}\text { Reciprocal } \\
\text { of above }\end{array}$ & $\begin{array}{l}\text { If activity } i \text { has one } \\
\text { of the above non- } \\
\text { zero numbers } \\
\text { assigned to it when } \\
\text { compared with } \\
\text { activity } j \text {, then } j \text { has } \\
\text { the reciprocal value } \\
\text { when compared } \\
\text { with } i \text {. }\end{array}$ & $\begin{array}{l}\text { A reasonable } \\
\text { assumption }\end{array}$ \\
\hline $1.1-1.9$ & $\begin{array}{l}\text { If the activities are } \\
\text { very close }\end{array}$ & $\begin{array}{l}\text { May be difficult to } \\
\text { assign the best value } \\
\text { but when compared } \\
\text { with other contrasting } \\
\text { activities the size of the } \\
\text { small numbers would } \\
\text { not be too noticeable, } \\
\text { yet they can still } \\
\text { indicate the relative } \\
\text { importance of the } \\
\text { activities }\end{array}$ \\
\hline
\end{tabular}

\section{Using piping and instrumentation diagram (P\&ID) as a foundation for data management}

In this work, a node system technique based on P\&ID is used to manage and track documents of the process hazards. Figure 1 shows the framework of how P\&ID is utilized in managing HAZOP-AHP information within a pilot plant. The P\&ID is divided into several nodes and generally as similar as HAZOP study node. The HAZOP-AHP implementation for each node is carried out according to HAZOP-AHP framework ${ }^{16}$. Once information has been analysed, compiled and updated for the selected equipment or streams, the end users can choose next equipment or stream within the selected node for HAZOP-AHP. After all the identified hazards within the selected node have been ranked, the end users can choose next node of the pilot plant. The process will continue until all nodes in the P\&ID are completed.

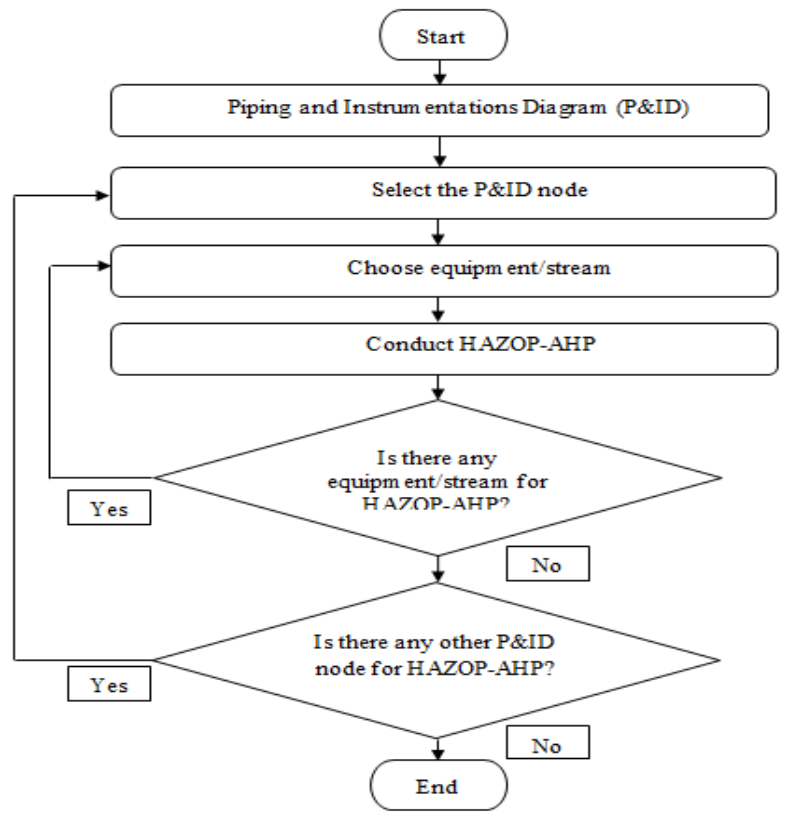

Figure 1: Process flow of HAZOP-AHP data management using $\mathrm{P} \& \mathrm{ID}$ as a foundation.

\section{Case Study}

To demonstrate the developed concept, a case study was conducted using the high pressure $\mathrm{CO}_{2-}^{-}$ hydrocarbon absorption pilot plant at Universiti Teknologi PETRONAS. The pilot plant is used to study the absorption performance of amine solvent in removing carbon dioxide $\left(\mathrm{CO}_{2}\right)$ from the natural-gas stream for pressure of up to 80 bars. Since the pilot plant is handling a flammable gas at a high pressure condition, it is a compulsory requirement by the university that the test rig is subjected to process hazard assessment and management. The objective of this study is to identify the main cause or possible hazards that could contribute to fire event. Referring to the concept illustrated in above section, Figure 2 shows the selected node for this case study, which consists of absorption column (AC01/AC02) with inlet and outlet streams. The corresponding HAZOP analysis for this node is shown in Table 2. 


\section{Chemical Engineering Research Bulletin 19(2017) 87-95}

Table 2: Selected HAZOP study of CHAS Pilot Plant.

\begin{tabular}{|c|c|c|c|c|c|c|}
\hline Item & Process Parameters & $\begin{array}{l}\text { Deviation } \\
\text { (guideword) }\end{array}$ & Possible Causes & Possible Consequences & Safeguards & Recommendation \\
\hline \multirow[t]{2}{*}{$4 \mathrm{~A}$} & Level & More & $\begin{array}{l}\text { 1. Actuator PV } 01 / 02 \\
\text { failed and stuck closed. }\end{array}$ & $\begin{array}{l}\text { 1. Back flow from inlet line of AC } 01 / 02 \\
\text { causes internal compressor COM } 01 / 02 \\
\text { damage resulting leak of used solvent and } \\
\text { mixture gas. Any available ignition source } \\
\text { could cause fire. }\end{array}$ & $\begin{array}{l}\text { 1. High level indicator } \\
\text { LS01/03 } \\
\text { 2. Direct drain HV } 31 / 32\end{array}$ & $\begin{array}{l}\text { 1. Regular functionality } \\
\text { check of PV } 01 / 02 \text {. } \\
2 . \text { To install new check valve } \\
\text { before ball valve HV33 and } \\
\text { HV34 }\end{array}$ \\
\hline & & & $\begin{array}{l}\text { 2. NV01/02 failed and } \\
\text { stuck closed. }\end{array}$ & $\begin{array}{l}\text { 1. Back flow from inlet line of AC } 01 / 02 \\
\text { causes internal compressor CM } 01 / 02 \\
\text { damage resulting leak of used solvent and } \\
\text { mixture gas. Any available ignition source } \\
\text { could cause fire. }\end{array}$ & $\begin{array}{l}\text { 1. High level indicator } \\
\text { LS01/03 via PLC } \\
\text { 2. Direct drain HV 31/32. }\end{array}$ & $\begin{array}{l}\text { 1. Regular functionality } \\
\text { check of NV01/02 } \\
\text { 2. To install new check valve } \\
\text { before ball valve HV33 } \\
\text { and HV34 }\end{array}$ \\
\hline $4 \mathrm{D}$ & Temperature & More & $\begin{array}{l}\text { 1. Initial reaction between } \\
\text { solvent and } \mathrm{CO} 2 \text {. }\end{array}$ & $\begin{array}{l}\text { 1. Overheated AC } 01 / 02 \text { causes leak at } \\
\text { sampling joint resulting release of mixture } \\
\text { gas and hot solvent. Any available ignition } \\
\text { source could cause fire. }\end{array}$ & 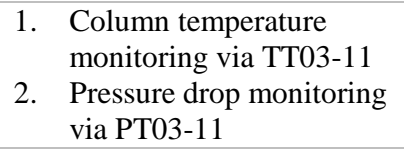 & \\
\hline \multirow[t]{2}{*}{$4 \mathrm{E}$} & \multirow[t]{2}{*}{ Pressure } & \multirow[t]{2}{*}{ More } & $\begin{array}{l}\text { 1. HV 29/30 fail and stuck } \\
\text { closed }\end{array}$ & $\begin{array}{l}\text { 1. Overpressure in AC01/02 up to max } \\
\text { COM01/02 pressure ( } 150 \text { bar) cause } \\
\text { column rupture resulting release of mixture } \\
\text { gas and hot solvent. Any available ignition } \\
\text { source could cause fire. }\end{array}$ & $\begin{array}{l}\text { 1. Pressure increment } \\
\text { monitoring via PT03-11 } \\
\text { 2. COM01/02 manual } \\
\text { shutdown once P exceed } \\
80 \text { bar }\end{array}$ & $\begin{array}{l}\text { 1. Regular functionality } \\
\text { check of HV29/30 } \\
\text { 2. To install new pressure } \\
\text { relief valve after BPV } \\
01 / 02\end{array}$ \\
\hline & & & $\begin{array}{l}\text { See more level cause } 1 \text { at } \\
4 \mathrm{~A}\end{array}$ & & & \\
\hline
\end{tabular}




\section{Chemical Engineering Research Bulletin 19(2017) 87-95}

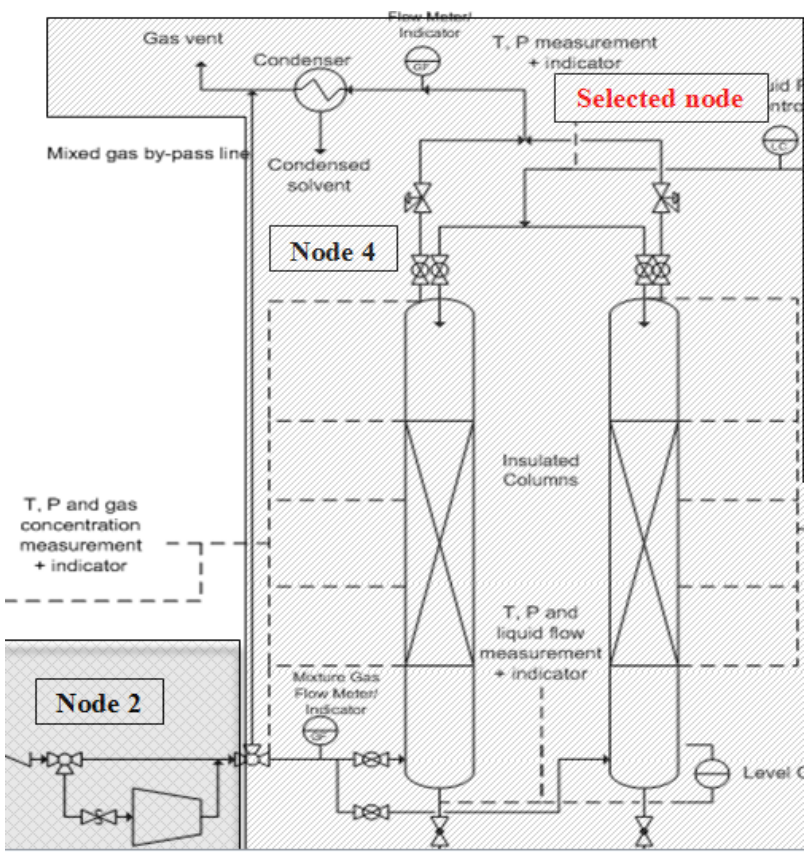

Figure 2: Part of the CHAS P\&ID showing selected node.

\section{Problem decomposition hierarchy}

Problem decomposition is very important in decision making. After the HAZOP analysis table is constructed, the next step is to decompose the problem into a hierarchical form. Figure 3 shows the hierarchical problem decomposition of the selected nodes. The analysis goal is to identify the main cause or possible hazards that could contribute to fire event. The goal is then expanded to the second level or criteria that represent the boundary analysis node which is in this case, the absorption column. The third level or sub-criteria is the related process parameter including level, temperature and pressure. For each process parameters, it will be further broken down to the fourth level which describes the deviation of the parameters which is 'more'. The fifth level is the causes which indicate condition that give rise to the deviation parameters.Finally in the last level of the hierarchy are the alternative or possible consequences anticipated due to the deviation of the parameter which directly contribute to the significant operation and safety issues.

\section{Pairwise comparison}

A pairwise comparison is performed at every level. The comparison process can be aided using series of questions that relates the relationship of the compared elements and the control criterion. For example in this case, in the third level the question was raised 'How much important is level compared to the temperature when performing HAZOP at the selected node (Node
4)'. In this question, level acts as the base criterion while temperature is the paired criteria and the performing HAZOP at the absorption column AC01/02 (Node 4) is the control criterion. Table 3 shows that pressure is identified as the most important parameter in contributing to hazards with relative weight of 0.64833 . It is followed by level and temperature which have relative weight of 0.22965 and 0.12202 , respectively. These values indicate that 'pressure' is the most anticipated parameter to be considered in conjunction with HAZOP analysis for the AC 01/02 followed by level and temperature. Based on the parameter deviation (fourth level), the results are tabulated in Table 4. It shows that MORE pressure (3.1) is anticipated to cause to the highest process deviation with the relative weight of 0.70097 , followed by MORE level (1.1) and MORE temperature which have 0.19288 and 0.10615 of relative weight respectively. Based on three deviations of parameters, deviation of MORE pressure is crucial compared to the other deviation. All the consistency ratios are below than $10 \%$, thus the pairwise judgments that have been made can be trusted.

Table 3: Priorities result based on parameters.

\begin{tabular}{|l|l|l|}
\hline & Parameter & Priorities \\
\hline 1.0 & Level & 0.22965 \\
\hline 2.0 & Temperature & 0.12202 \\
\hline 3.0 & Pressure & 0.64833 \\
\hline
\end{tabular}

Table 4: Priorities result based on parameters deviations.

\begin{tabular}{|l|l|l|}
\hline & $\begin{array}{l}\text { Parameter } \\
\text { Deviation }\end{array}$ & Priorities \\
\hline 1.1 & More & 0.19288 \\
\hline 2.1 & More & 0.10615 \\
\hline 3.1 & More & 0.70097 \\
\hline
\end{tabular}




\section{Chemical Engineering Research Bulletin 19(2017) 87-95}

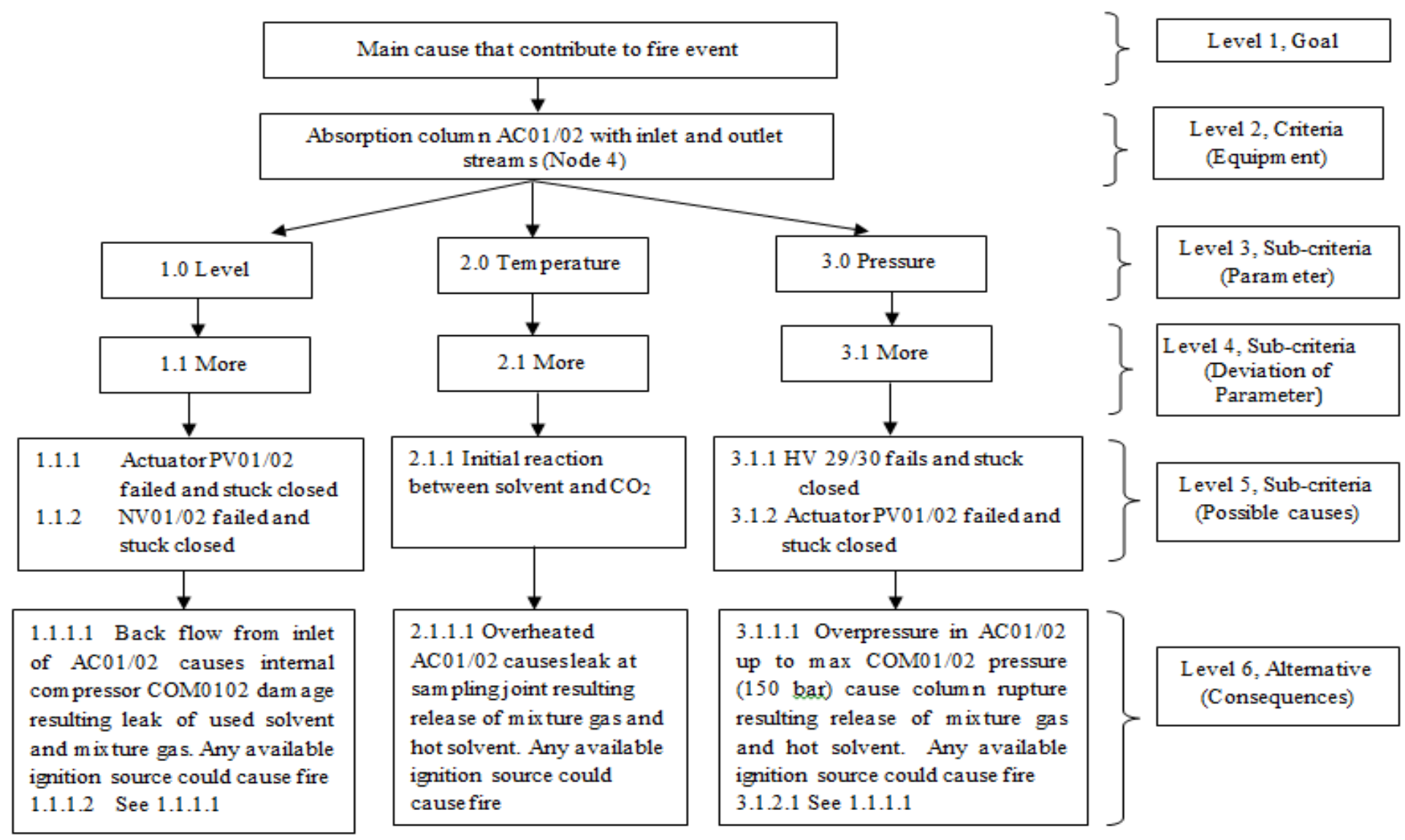

Figure 3: Hierarchical problem decomposition for the absorption column (AC 01/02). 


\section{Chemical Engineering Research Bulletin 19(2017) 87-95}

Table 5 shows the synthesized priorities for the consequences (alternatives) of absorption column AC01/02 based on cause of deviation. The Normals column presents the results in the form of the priorities. The Ideals column is obtained from Normals column by dividing each of the value with the largest value in the column. Thus, the best choice has a priority of 1. Based on the SDS synthesis, the consequence of AC 01/02 column rupture (3.1.1.1) has the highest priority of 0.4862 . The lowest priority is referred to damage to compressor COM 01/02 (1.1.1.1 and 1.1.2.1) with the Normals value of 0.1148 .

Table 5: The weight of the consequences from SDS.

\begin{tabular}{|c|c|c|}
\hline Alternative (Consequences) & Ideals & Normals \\
\hline $\begin{array}{l}\text { 1.1.1.1 Back flow from inlet line } \\
\text { of AC 01/02 causes } \\
\text { internal compressor } \\
\text { COM 01/02 damage } \\
\text { resulting leak of used } \\
\text { solvent and mixture gas. } \\
\text { Any available ignition } \\
\text { source could cause fire. }\end{array}$ & 0.2361 & 0.1148 \\
\hline $\begin{array}{l}\text { 1.1.2.1 Back flow from inlet line } \\
\text { of AC 01/02 causes } \\
\text { internal compressor COM } \\
\text { 01/02 damage resulting } \\
\text { leak of used solvent and } \\
\text { mixture gas. Any available } \\
\text { ignition source could cause } \\
\text { fire. }\end{array}$ & 0.2361 & 0.1148 \\
\hline $\begin{array}{l}\text { 2.1.1.1 Overheated AC } 01 / 02 \\
\text { causes leak at sampling } \\
\text { joint resulting release of } \\
\text { mixture gas and hot } \\
\text { solvent. Any available } \\
\text { ignition source could cause } \\
\text { fire. }\end{array}$ & 0.2509 & 0.1220 \\
\hline $\begin{array}{l}\text { 3.1.1.1 Overpressure in AC01/02 } \\
\text { up to max COM01/02 } \\
\text { pressure ( } 150 \text { bar) cause } \\
\text { column rupture resulting } \\
\text { release of mixture gas and } \\
\text { hot solvent. Any available } \\
\text { ignition source could cause } \\
\text { fire. }\end{array}$ & 1.0000 & 0.4862 \\
\hline $\begin{array}{l}\text { 3.1.2.1 Back flow from inlet line } \\
\text { of AC 01/02 causes } \\
\text { internal compressor COM } \\
\text { 01/02 damage resulting } \\
\text { leak of used solvent and } \\
\text { mixture gas. Any available } \\
\text { ignition source could cause } \\
\text { fire. }\end{array}$ & 0.3333 & 0.1621 \\
\hline
\end{tabular}

Table 6 shows the enhanced version of HAZOP analysis table incorporating the AHP analysis for hazard prioritization. From this, it is shown that activity 3.1.1 (HV 29/30 fail and stuck closed) is the most significant causes of fire event in the absorption column AC 01/02, this is followed by 3.1 .2 (Actuator PV 01/02 failed and stuck closed), 2.1.1 (initial reaction between solvent and $\mathrm{CO} 2$ ), 1.1.1 (Actuator PV 01/02 failed and stuck closed) and 1.1.2 (NV 01/02 failed and stuck closed).HAZOP-AHP started according to the deductive approach (downward) postulating top events (deviations), and then followed the inductive method (upward) asking what would happen to the system. This definition revealed the reason for the success of HAZOP and underscored its widespread usage compared to other well-known analysis systems.By identifying the most significant causes, the engineers/researchers could take appropriate action associated with the prioritized cause for inherently safer process design. In addition, by having systematic PHA data management overlook of process hazards can be prevented.

\section{Conclusion}

In this paper, the application of AHP in prioritizing HAZOP analysis for pilot plant is presented. The method has been applied to high pressure $\mathrm{CO} 2$ hydrocarbon absorption system pilot plants as case study. The results show that, HAZOP-AHP methodology is able to identify and rank the most significant hazards among the identified list of hazards. This is particularly useful as a leading indicator to process designers/engineers/researcher in prioritizing their efforts and resources on more significant hazards, hence prevent accidents of the pilot plant.Anyhow, in AHP,relative measurements about pairwise comparison ratios with respect to the strength of preference between elements of comparison are based on human intuition. Therefore, the decision makers need to express their opinion regarding the value of single pairwise comparison at a time and need to choose their answer based on the Saaty (1980) evaluation scale.

\section{Acknowledgement}

We gratefully acknowledge the financial support from the Malaysia Ministry of Education through ERGS (RDU130601) and Centre of Advanced Process Safety at UniversitiTeknologi PETRONAS for data sharing that make this study feasible. 


\section{Chemical Engineering Research Bulletin 19(2017) 87-95}

Table 6: Prioritizing HAZOP analysis using analytic hierarchy process (AHP).

\begin{tabular}{|c|c|c|c|c|c|c|c|c|}
\hline Goal & Study node & Parameter & Deviation & Causes & Consequences & Normal & Rank & Action \\
\hline \multirow[t]{5}{*}{$\begin{array}{l}\text { Main } \\
\text { cause that } \\
\text { contribute } \\
\text { to fire } \\
\text { event }\end{array}$} & \multirow[t]{5}{*}{$\begin{array}{l}\text { Absorption } \\
\text { column AC } \\
01 / 02 \text { with } \\
\text { inlet and } \\
\text { outlet } \\
\text { streams }\end{array}$} & 1.0 Level & 1.1 More & $\begin{array}{l}\text { 1.1.1 Actuator PV } \\
01 / 02 \text { failed and } \\
\text { stuck closed. }\end{array}$ & $\begin{array}{l}\text { 1.1.1.1Back flow from inlet line } \\
\text { of AC 01/02 causes internal } \\
\text { compressor COM } 01 / 02 \text { damage } \\
\text { resulting leak of used solvent and } \\
\text { mixture gas. Any available } \\
\text { ignition source could cause fire. }\end{array}$ & 0.1148 & 4 & $\begin{array}{l}\text { 1. Regular functionality } \\
\text { check of PV 01/02. } \\
\text { 2. To install new check } \\
\text { valve before ball } \\
\text { valve HV33 and } \\
\text { HV34 }\end{array}$ \\
\hline & & & & $\begin{array}{l}1.1 .2 \mathrm{NV01/02} \\
\text { failed and stuck } \\
\text { closed. }\end{array}$ & $\begin{array}{l}\text { 1.1.2.1Back flow from inlet line } \\
\text { of AC 01/02 causes internal } \\
\text { compressor COM } 01 / 02 \text { damage } \\
\text { resulting leak of used solvent and } \\
\text { mixture gas. Any available } \\
\text { ignition source could cause fire. }\end{array}$ & 0.1148 & 5 & $\begin{array}{l}\text { 1. Regular functionality } \\
\text { check of NV01/02 } \\
\text { 2. To install new check } \\
\text { valve before ball } \\
\text { valve HV33 and } \\
\text { HV34 }\end{array}$ \\
\hline & & 2.0 Temperature & 2.1 More & $\begin{array}{l}2.1 .1 \text { Initial } \\
\text { reaction between } \\
\text { solvent and } \mathrm{CO} 2 \text {. }\end{array}$ & $\begin{array}{l}\text { 2.1.1 1. Overheated AC 01/02 } \\
\text { causes leak at sampling joint } \\
\text { resulting release of mixture gas } \\
\text { and hot solvent. Any available } \\
\text { ignition source could cause fire. }\end{array}$ & 0.1220 & 3 & \\
\hline & & 3.0 Pressure & 3.1 More & $\begin{array}{l}\text { 3.1.1 HV 29/30 } \\
\text { fail and stuck } \\
\text { closed }\end{array}$ & $\begin{array}{l}\text { 3.1.1.1 Overpressure in AC01/02 } \\
\text { up to max COM01/02 pressure } \\
(150 \text { bar) cause column rupture } \\
\text { resulting release of mixture gas } \\
\text { and hot solvent. Any available } \\
\text { ignition source could cause fire. }\end{array}$ & 0.4862 & 1 & $\begin{array}{l}\text { 1. Regular functionality } \\
\text { check of HV29/30 } \\
\text { 2. To install new } \\
\text { pressure relief valve } \\
\text { after BPV } 01 / 02\end{array}$ \\
\hline & & & & $\begin{array}{l}\text { 3.1.2 Actuator PV } \\
01 / 02 \text { failed and } \\
\text { stuck closed. }\end{array}$ & $\begin{array}{l}\text { 3.1.2.1 Back flow from inlet line } \\
\text { of AC 01/02 causes internal } \\
\text { compressor COM } 01 / 02 \text { damage } \\
\text { resulting leak of used solvent and } \\
\text { mixture gas. Any available } \\
\text { ignition source could cause fire }\end{array}$ & 0.1621 & 2 & $\begin{array}{l}\text { 1. Regular functionality } \\
\text { check of PV } 01 / 02 \text {. } \\
\text { 2. To install new check } \\
\text { valve before ball valve } \\
\text { HV33 and HV34 }\end{array}$ \\
\hline
\end{tabular}




\section{Chemical Engineering Research Bulletin 19(2017) 87-95}

\section{References}

1. T. Reinart, "Hiddon pilot plant hazards,"Journal of Chemical Safety and health, vol. January/February, pp. 26-27, 2003.

2. N. Langerman, "Laboratory safety?,"Journal of Chemical Health and Safety, vol. 16, no. 3, pp. 4950, 2009.

3. B. L. Banderly, "Taken for granted: The burning question of laboratory safety," AAS \& Science, Washington, DC, 2009.

4. D. Hendershot, "Process Safety Culture," Journal of Chemical health \& Safety, Virtual issue, 2007.

5. E. Mason, "Pilot plants and the lab standard,"Journal of Chemical Health and Safety, vol. 7, no.2, pp. 16-18, 2000.

6. A. S. West, "Plant Process Safety Starts in the Laboratory," Journal of Chemical and Health Safety, vol, March/April, pp. 15-17, 1999.

7. N. Langerman, "Lab-scale process safety management,"Journal of Chemical Health \& Safety, vol. July/August, pp. 22-28, 2009.

8. H. A. Aziz,A.M. Shariff and M.R. Roslan, "Managing Process Hazards in Lab-Scale Pilot Plant for Safe Operation" American Journal of Engineering and Applied Sciences, vol. 5, no.1, pp. 84-88, 2012.

9. J. Dunjo, V. Fthenakis, J.A. Vilchez and J. Arnaldos, "Hazard and operability (HAZOP) analysis. A literature review," Journal of Hazardous Materials, vol.173, no.1-3, pp.19-32, 2010.

10. F. I. Khan, and S.A. Abbasi, "Techniques and methodologies for risk analysis in chemical process industries," Journal of Loss Prevention in the Process Industries," vol.11, no.4, pp. 261-277, 1998.
11. D. A. Crowl and J.F. Louvar, "Chemical Process Safety: Fundamentals with Applications," Eaglewood Cliffs, New Jersey, Prentice Hall, 2002.

12. D.Narayanan, Y. Zhang and M.S. Mannan, "Engineering for sustainable development in biodiesel production,"Process Safety and Environmental Protection,", vol.85, pp. 349-359, 2007.

13. L. A. Hadidi, and M.A. Khater, "Loss prevention in turnaround maintenance projects by selecting contractors based on safety criteria using the analytic hierarchy process $(A H P)$, ,Journal of Loss Prevention in the Process Industries," vol.34, pp. 115-126, 2015.

14. A. C. Caputo, P.M. Pelagagge and P. Salini, "AHP-based methodology for selecting safety devices of industrial machinery,"Safety Science, vol. 53, pp. 202-218, 2013.

15. L. Lu, W. Liang, L. Zhang, H. Zhang, Z. Lu, and J. Shan, "A comprehensive risk evaluation model for natural gas pipelines by combining a risk matrix with a bow-tie model," Natural Gas Science and Engineering, vol. 25, pp. 124-133, 2015.

16. M. R. Othman, R. Idris, M. H. Hassim andW.H. Wan Ibrahin, "Prioritizing HAZOP analysis using analytic hierarchy process (AHP)," Journal of Clean Technology Environment Policy,"vol.18, no.5, pp. 1345-1360, 2016.

17. S. Baby, "AHP modeling for multicriteria decision making and to optimise strategies for protecting coastal landscape resources," Innovation Management and Technology, vol.4, no.2, pp. 218-227, 2013.

18. T. L. Saaty, "The Analytic Hierarchy Process,"New York, McGraw-Hill, 1980.

\section{Available online at http://www.banglajol.info/index.php/CERB}

Publisher: Department of Chemical Engineering, Bangladesh University of Engineering and Technology (BUET). Review \&Publication: A submitted original manuscript is taken into review only if the uniqueness is found to be more than $85 \%$ in plag-scanning and selected for publication by the complete acceptance from at least two reviewers out of three. Home Page: http://www.banglajol.info/index.php/CERB. Indexed by Chemical Abstract Service (CAS), CEABA-VtB, Google Scholar, Scopus and DOAJ. 